\title{
An Approach to civilization of the rule by law of religious affairs
}

\author{
Nai Peng \\ Law School of Yunnan University of \\ of Finance and Economics \\ Kunming, China \\ (863193534@qq.com)
}

\author{
*Chen Xiaolong \\ Law School of Yunnan University \\ of Finance and Economics \\ Kunming, China \\ (672401796@qq.com)
}

\author{
Wang Yandi \\ the Tianjin High People's Court \\ Tianjin, China \\ (1017501272@qq.com)
}

\begin{abstract}
Either guiding by the principle of fundamental rights in Constitution or driven by the innate characters of Civil Law, the Civil Law codification must consider the religion and minority issues. In fact, we are delight to see that substantial achievements of the religious legal person and religious property were gained. But it is not enough, when we took the systematic character of civil code and multitudes of facets to religious affairs into account. Meanwhile, the Legislative Affairs Committee of P.R.China has decided to boot up enactment of general principles as the leading part of civil legal codification. This part may involve legislative philosophy and fundamental rights effect and fundamental principles and resource of law and the civil subject system and civil juristic acts, even the personality law.
\end{abstract}

Keywords—religious affairs; civil code; fundamental right

\section{INTRODUCTION}

The rule of law in religion have been lucubrated by numerous civil jurists who are willing to plead for the mass, plentiful and substantial achievements were gained.

Sun Xianzhong intensively studied the law systems of the religious legal person and religious property as early as 1990(Sun Xianzhong,1990 ) . In time of China's civil Code being compiled, issues of the religious legal person and religious property had gained wide attention. Article 84 of General Principles of the Civil Law of the People's Republic of China (Draft, China law society) definied of the religious legal person as a kind of legal body of financial group (China law society,2015) . Article 19 of General Principles of the Civil Law of the People's Republic of China (Draft, Yang) stipulated principle of freedom of religious belief (Yang Lixin, 2015). There were dichotomous classifications of legal system of religious legal person, either by social group or by financial group. Some jurists classified it by "profit organization/nonprofit organization" from functional aspect. Others suggested that the law systems of the religious legal person could be stated by a normal issue in Civil Law but should be legislated by a specific law from legislation aspect.

\section{Codification of Civil Code And Rule BY LAW OF RELIGIOUS AFFAIRS}

\section{A. Fundamental rights of religion must be upheld throughout the legal system}

The Constitution and Civil Law are the basic law of civil life (Xie Hongfei, 2015) . Religious affairs involved law of education, employment, association, personality rights , property, contract and kinship. Thus, the rule of law in religion should be achieved by the corporation of public and private law under the rule of Constitution. The shortcoming of current dual administrative mode "Administration-Legal institution" of religious affairs could be overcome by innovation of the rule of law in religion-"broaden the application of Civil Law by switching from administration to govern "(Wang Liming, 2015). Fundamental rights must be upheld throughout the legal system, especially considering no Constitution Law suit would be accepted by the courts in China. So the legislation of private law of the freedom of religion belief in Constitution, construction and protection of the legal system of the rule of law of religious legal person and religious property is of great importance to improve religion administration, desensitize religious affairs, eliminate extremism in religious affairs, secularize religious affairs and promote the level of legalized management of religious affairs.

\section{B. Civil code with the eyes of a mother looks religious affairs}

Civil law cannot exclude the religious affairs by itself. "Wherever it is, the Civil Code is always considered as the core of legal system (Alan Watson, 2005). And rightsstandard (Wang Zejian, 2009) , the innate characters of Civil Law as rights standard endowed itself an self-evident important role in legal system, Civil Code with the eyes of a mother (Montesquieu) won' $\mathrm{t}$ ignore the rights and interests of religions. The essence of Civil Code as "General-special provisions" (Wang Liming, 2015) was predestined that the interplay between Civil Code and rule of law in religion should not be limited in religious legal person and religious property but should be considered in an architectural view (Cui Jianyuan, 2014). The civil legal codification should face the history, future, citizen lives and national cultures, meanwhile maximize 
the benefits through meticulous technology and systemization. We hold Privatautonomie as the first value of civil code, and also must show respect for the traditional values such as morality, developing for the people, harmony (Xie Hongfei, 2015 ) . Furthermore, the excellent ideals of traditional cultures and religions could pay the civil law back for making the rules strike roots in people' $s$ hearts (Wang Liming, 2015 ) . Therefore, either guided by the principle of fundamental rights in Constitution or driven by the innate characters of Civil Law, the Civil Law codification must consider the religion and minority issues.

\section{Special LaW of Civil Code AND RELIGIOUS AFFAIRS}

\section{A. Civil law and fundamental right of freedom in religious belief}

Specifically, German scholars put forward different doctrines: the direct effect theory, the indirect effort theory and "duty to protect" when they talked about the relationship between fundamental rights and Civil Law (Canaris, 2013). It's a positive fundamental issue in our law system. According to these different doctrines, Civil Law approaches to protect this fundamental right of freedom of religious belief will be significantly different.

\section{B. Source of Civil Law and religion}

The Swiss Civil Code Art.1: the law applies according to its wording or interpretation to all legal questions for which it contains a provision. In the absence of a provision, the court shall decide in accordance with customary law and, in the absence of customary law, in accordance with the rules that it would make as legislator. In doing so, the court shall follow established doctrine and case law (Li Min, 2015). The Swiss Civil Code has confirmed three sources of law for the first time as established doctrine, customary law and case law. However, the relationships between canons, religious customs, ethnic customs and civil law, the principle of public order and good consideration required in-depth study.

\section{Personality law and religion}

Divergent views have existed as to the position of personality rights as an independent part in Civil Code or not (Long Weiqiu, 2012, 2013). Most scholars have agreed to the legalization of personality rights in Civil Code in China, although opposite arguments are convincing (Yin Tian, 2015). However, the personality right is highly abstract and hard to clearly defined, it was fist emerged from Constitution and once been sidestepped in Civil Code. Right of freedom of religious belief was naturally intimate to_personality right, such as abstractness, origins and complicacy. But the relationship between them needed to be considered carefully. For example, religious rights of reputation are more complicated than common (there are multitudes of experience and information that we should evaluate and utilize from Charlie Hebdo Event) (Mu Mingchun, 2015). The relationship between religious halidom and personalized things also needed to be pondered.

\section{Real right law and religion}

In property right chapter, the rule of law of religious affairs may involve the following parts: the fact rights of things of religion, religious neighboring relations, and ecclesiastical property rules and so on. For instance, Myanmar's decision to suspend the construction of Chinese-backed Myitsone dam, and ignoring local belief was probably a factor in the Myitsone dam decision (Li Li, 2015).

\section{E. The legal acts and religion}

The legal acts are subject to restrictions by fundamental right of freedom of religious belief. Obergefell v. Hodges, decided in June 26 2015, is a landmark of United States Supreme Court case in which the Court held in a 5-4 decision that the fundamental right of marriage is guaranteed to same-sex couples by both the Due Process Clause and the Equal Protection Clause of the Fourteenth Amendment to the United States Constitution. It is a complicated problem to solve the underlying contradiction between the Equal Protection of gays and right of freedom of religious belief. For instance, does a believer have right to refuse to service a couple of gays for his belief? In 2015, a couple of gays sued Furong district of Changsha civil affairs bureau for refusing their marriage applicants. Different kinds of rights and interests derived from fundamental right of freedom of religious belief have different effect basic on account of the distance between these kinds of rights and interests and personality rights.

\section{$F$. The tort law and religion}

Above all, there are many possible solutions for civilizing of fundamental right of freedom of religious belief. Perhaps we could create principle of freedom of religious belief, such as article19 of General Principles of the Civil Law of the People's Republic of China (Draft, Yang)(Yang Lixin, 2015); or applying principle of public order and good custom and tort law to protect religious rights; or protecting religious rights by creating special provisions in part of personality rights law. According to the regulation "this law is formulated for the purpose of protecting the legitimate rights and interests of civil subjects" of article 1 in Tort Law of the People's Republic of China, some jurists considered this law as a law of remedy. Even the norm of this law, tort liability different from tort obligation, has manifested its role (Long Weiqiu, 2012). The religious rights and interests must be protected and coordinated with general principles, the property right and obligation of right between the future Civil Code and tort law. The abstract nature of Civil Code did not necessitate itself to specific respond to these affairs, we could create only general and necessary provisions for regulating by special laws and developing it in practice to build up Civil Law mode with different department civil laws. In one word, only Civil Code is not the department mode of civil law we need. 


\section{CONClusion Legislation OF GENERAL PROVISIONS OF CIVIL LAW IS AN OPPORTUNITY FOR RULE OF LAW IN RELIGION}

The Legislative Affairs Committee of P.R. China has decided to boot up enactment of general principles as the leading part of civil legal codification. "General Principles of Civil Law" is the basis of establishment of civil code (Wang Liming, 2015). Religious affairs may involve legislative philosophy and fundamental rights effect and fundamental principles and resource of law and the civil subject system and civil juristic acts. Furthermore, scholars have not come to an agreement on whether the personality right should be an independent part of civil code. But the personality right will be close to the general principles under any possible mode. Confined to the length of the thesis, we just discussed issues of legislative philosophy and fundamental rights.

\section{A. Legislative philosophy and religion}

Relationship among law, religion and morality is a classical and enduring topic (Roscoe Pound, 1924). While law does not compel people to pursue some faith and virtues, it also does not prevent and restrict pursuit for faith and virtues. Furthermore, it is very important to prevent mankind against depravation by the mysterious hand of the legislator, and the legislator's virtue is of same importance. According to "religious prosociality hypothesis" (Ahmed, A. M. 2009), Social scientists and folk wisdom both claimed that there was an association between religiosity and prosocial behavior. The legislator should show their understanding and respect to religious affairs, facing up to positive effect of religion. Indeed well-ordered Chinese religious ecology may promote civil code melting into our national life. For example, culture of Buddhist religious disciplines and principle of public order and moral may complement each other (Ma Zhiguo, 2010).

\section{B. Fundamental right of freedom of religious belief}

Article 36 in Constitution of China stipulates:

"No state organ, public organization or individual may compel citizens to believe in, or not to believe in, any religion; nor may they discriminate against citizens who believe in, or do not believe in, any religion. The state protects normal religious activities. No one may make use of religion to engage in activities that disrupt public order, impair the health of citizens or interfere with the educational system of the state. Religious bodies and religious affairs are not subject to any foreign domination. "

From the fact that freedom of religious belief involves education, employment, association, personality rights, property, contract, kinship and so on, we can conclude that the right must suffuse the civil law system. It is logical to protect the fundamental freedom of religious belief in Constitution by enact of private law in Civil Lay codification to implementation of freedom of religious belief. It is usually agreed that Pandekten System should be applied in civil law, protection of the fundamental right of freedom of religious belief by civilization approach means constituting the basic claim procedure of that right. At the same time, the fundamental right of freedom of religious belief of article 36 of Constitution of the People's Republic of China could be split into three aspects, the freedom of religious belief right, the equality of people choosing religious belief, the ability of free legal religious exercise. The approaches and effect of the three aspects of article 36 of constitution are different according to their characters.

\section{ACKNOWLEDGMENT}

Much thanks to our families, friends and colleagues. We are very grateful to the organizer for the chance of sharing our opinions.

\section{REFERENCES}

[1] Sun Xianzhong (1990). Consortium legal person property rights and religious property ownership problem, Study of science of civil law. (in Chinese)

[2] China Law Society (2015). General Principles of the Civil Law of the People's Republic of China (Draft, China law society). (in Chinese)

[3] Yang Lixin (2015).General Principles of the Civil Law of the People's Republic of China (Draft, Yang) (in Chinese)

[4] Xie Hongfei (2015). The civil code and human virtue. China Law Review. (in Chinese)

[5] Wang Liming (2015). The compilation of civil code in comprehensively deepening the reform. China Law science. (in Chinese)

[6] Alan Watson, Li jingbing and Yao Xinhua translated, (2005). The making of the civil law. China legal publishing house.

[7] Wang Zejian (2009). General principles of civil law. Peking university press. (in Chinese)

[8] Cui Jianyuan (2014). Several problems must be solved before the codification of civil code. Tsinghua Law Journal. (in Chinese)

[9] Canaris. Grundrechte und Privatrecht,-eine Zwischenbilanz-,Berlin,New York 1999.

[10]Li Min (2015). The Famous Art . 1 of Swiss Civil Code: Legal

Thoughts, Methodology and Judicial Practice. Journal of comparative law. (in Chinese)

[11]Long Weiqiu (2013). The basis of China codification of civil code. Journal of China University of Political science and Law. (in Chinese)

[12]Yin Tian (2015). A Re-criticism of Personality Right as an Independent Part. Journal of comparative law. (in Chinese)

[13]Mu Mingchun (2015). Right of freedom of speech over the controversy. Journalism and Communication. (in Chinese)

[14]Li Li (2015). Using the ISO26000 to improve go-global Chinese enterprises. Journal of University of International Business and Economics. (in Chinese)

[15]Long Weiqiu (2012). Basis and developments of tort law. Social science in China. (in Chinese)

[16]Ahmed, A. M. (2009). Are religious people more prosocial? A quasiexperimental study with madrasah pupils in a rural community in India. Journal for the Scientific Study of Religion, 48(2), 368-374.

[17]Ma Zhiguo (2010). Study on he Relation between Buddhism and Modern Secular Law. Journal of Xi'an Jiaotong University (social science). (in Chinese) 